\title{
Social Media-Based Content towards Image Formation: A New Approach to the Selection of Sustainable Destinations
}

\author{
Mohammad Tipu Sultan ${ }^{1, *(\mathbb{D}}$, Farzana Sharmin ${ }^{1}\left(\mathbb{D}\right.$, Alina Badulescu $^{2}\left(\mathbb{D}\right.$, Darie Gavrilut $^{3}$ and Ke Xue $^{1, *}$ \\ 1 School of Media and Communication, Shanghai Jiao Tong University (SJTU), Shanghai 200240, China; \\ sharminf@sjtu.edu.cn \\ 2 Department of Economics and Business, University of Oradea, 410087 Oradea, Romania; \\ abadulescu@uoradea.ro \\ 3 Doctoral School of Economics, University of Oradea, 410087 Oradea, Romania; darie.gavrilut@gmail.com \\ * Correspondence: tipusultan_ctg@sjtu.edu.cn (M.T.S.); kxue@sjtu.edu.cn (K.X.)
}

\section{check for}

updates

Citation: Sultan, M.T.; Sharmin, F.; Badulescu, A.; Gavrilut, D.; Xue, K. Social Media-Based Content towards Image Formation: A New Approach to the Selection of Sustainable Destinations. Sustainability 2021, 13, 4241. https://doi.org/

$10.3390 /$ su13084241

Academic Editors: José Luís Abrantes, J. Andres Coca-Stefaniak and Mark Anthony Camilleri

Received: 19 February 2021

Accepted: 8 April 2021

Published: 11 April 2021

Publisher's Note: MDPI stays neutral with regard to jurisdictional claims in published maps and institutional affiliations.

Copyright: (c) 2021 by the authors. Licensee MDPI, Basel, Switzerland. This article is an open access article distributed under the terms and conditions of the Creative Commons Attribution (CC BY) license (https:// creativecommons.org/licenses/by/ $4.0 /)$.

\begin{abstract}
When addressing the ever-increasing role that social media plays in generating a clear image of the travel destination chosen by tourists, the research and specialty literature tends to be rather limited. Despite an increase in social media-generated content, the process is not yet fully understood, although research suggests the importance of two different factors (i.e., tour-operatorgenerated content and user-generated content) in influencing destination image formation. In this regard, the present paper aims to examine the most significant factors currently affecting the potential behavior of travelers towards the selection of sustainable destinations. What is more, another purpose of this paper is to explore the effects that tour-operator-generated content and user-generated content have upon the formation of the overall mediating destination image through cognitive and affective destination images. For the current analysis, a structural equation modeling (SEM) method was used in order to test the conceptual model. Data from Shanghai, China $(n=425)$ were used. The results demonstrate and establish that travel information sources (i.e., tour-operator-generated content and user-generated content) have a positive effect on destination image formation. The analytical results also revealed that in order to select a sustainable destination, travelers are influenced by tour-operatorgenerated content, as well as by user-generated content, with the effect of the latter being more important and influential. Travelers' use of social media content has played a key role in the formation of the overall destination image through the mediating effect of cognitive and affective destination images. This research thus provides valuable theoretical and practical implications for academics and practitioners alike, implications which are valuable for the fields of destination marketing and management. Furthermore, practitioners of the management of sustainable destinations can thus make use of the results throughout the entire decision-making process.
\end{abstract}

Keywords: affective destination image; cognitive destination image; overall destination image; sustainable destination; social media; tour-operator-generated content; user-generated content

\section{Introduction}

The use of communication technology is particularly important in the tourism industry, in which competition to attract tourists is the biggest concern for tourist destinations. In order to accomplish this, it is mandatory to enhance the visibility of the destination through an adequate online and social media presence [1]. Moreover, it is necessary to go beyond a basic understanding of how to use social media to promote relevant destinations. Social media content can influence a traveler's overall image in the selection of sustainable destinations. The information source has been identified as the key factor contributing to destination image formation. Furthermore, social media information sources contribute to the creation of new opportunities for tourism businesses, through which they can better explore and exploit the destination image [2-4]. Several studies have suggested that 
social media information sources have a positive effect on online destination image formation [5-7], and assist in expanding customer loyalty, satisfaction, and intention towards a destination choice. For this, social media can play an important role in searching for and sharing travel information. Moreover, social media also impacts travel decisions regarding which destination to select. Social media can be considered a significant, widely explored and reviewed source, fortifying and improving information from traditional sources such as friends and acquaintances, commercial agents, vendors, destination marketing organizations, advertising, mass media, guide books, or documentaries [8].

Various tourism service providers and destination marketing organizations (DMOs) transmit this information by using different web platforms which publish content, which includes but is not limited to details on the following: the destination, the available products, and various tourism-related services [9]. All of these are ongoing strategies, and thus try to better face information and communication technologies (ICT)-related challenges accordingly [10]. DMOs have taken advantage of the opportunities brought forward by the use of the available online platforms in order to customize tourism information and to better interact with tourists [11,12]. By using multimedia-enabled websites and social media, DMOs can better interact with consumers and influence the destination image formation process [13]. Value generation can be provided by social media interactivity, thereby enhancing the destination image in tourists' minds [14]. However, DMOs should be consistent in their use of social media in order to create a positive image among travelers. DMOs can also develop or coordinate the destination image [15]. Most notably, their positive and authentic content (i.e., tour-operator-generated content, henceforth noted as TOGC) influences the destination choice and intention of travelers [16], and contributes to the reshaping of the destination image. Travel agencies and tour-operators also produce and release content on social media in order to reach the community and attract their interest [17]. Consumers' participation and interaction with the TOGC gives direct feedback to marketers. Thus, tour-operators can better understand the needs and beliefs of customers, whilst consumers are enabled to take, comment, modify, diffuse, adapt or reject this content. The main reason why this occurs is because travel marketers can directly connect with tourists and influence their decision-making processes by making use of social media [15]. Nevertheless, the use of social media by DMOs is still largely experimental $[10,12]$, and its influence on destination image formulation has not yet been fully explored $[7,14]$. For this reason, the current study tries to explore the quality of social media information offered by destination marketing agents (i.e., tour operators), which can influence the destination image formation process to select a specific destination.

Besides this, social media-based user-generated content (UGC) has played a vital role in the tourism industry. The influence of UGC upon the dissemination of choices concerning the tourist decision-making process is ever-growing. UGC often competes with traditional travel content providers, classic media, tourism enterprises, and news agencies [18]. UGC is also establishing itself as a distinct tourism marketing and communication tool for travel advertisers. Travelers' engagement with social media provides an opportunity to produce interactive travel content and to exchange travel information in many different forms, such as pictures, words, videos, and audio [19]. Travelers have increasingly started sharing more information on social media, and given this constant interaction between various users, social media can be used as an effective and preferred method for interacting between individuals, organizations, and service providers [20]; at the same time, social media can be transformed into a virtual platform for learners, or explored as a channel of knowledgesharing between communities and learners [21]. Tourists can also share their travel stories through Facebook, Instagram, Twitter, YouTube, and TripAdvisor [22].

The image of a tourist destination often depends on information and content generated by travelers, suppliers, and marketers. Destination image plays two major behavioral roles. First, it influences the decision-making process of destination selection, and second, it helps to determine post-decision behaviors, such as participation, assessment, and future behavioral intentions to recommend $[23,24]$. Travelers are naturally diverse, and travel 
for different motives; as such, efforts aimed at recognizing and attracting them towards sustainable destinations are crucial [25]. As the previous study suggested, the destination image has a significant role in selecting tourist destinations, and it also influences their future visiting behaviors [9]. In other words, tourists who have a satisfactory destination image are more likely to intend to visit and recommend the destination to others [16]. Studies have discussed the role of social-media-based content in the formation of destination images $[15,26]$. Moreover, the relationship between a destination information source and the destination image formation is dependent on tour-operators, tourism managers, local government authorities, and stakeholders as well [27]. They are the ones who initiate the sustainable development of a destination image that improves and retains tourism patronage. Thus, the destination image is the traveler's total impression shaped by the assessment of different destination features and characteristics [24].

Social media communities, friends, family, travel documentaries, and past travel experience all affect a traveler's destination choice intention [28]. Tourism studies recommend that social media has enhanced effectiveness in travel decision-making and marketing strategies [29]. Various types of user-generated content (UGC)—such as blogs, online communities, and social networks (such as Instagram, YouTube, and Flickr)—have gained huge popularity regarding sustainable destination choices [30,31]. Most of these social media platforms enable consumers to post and share travel-related comments, views, and personal experiences, which further serve as information sources for others. Several studies have reported on the increasing role of search engines in generating upstream traffic to tourism websites [19]. As a result, search engines have operated as a 'gateway' for travel-related marketing channels, and have created a strong and influential information source, which has the power of convincing and attracting potential tourists [19]. According to Stepchenkova and Mills [32], destination image studies have been identified as major areas in the field of tourism due to their highly applied importance for destination management and marketing. Moreover, this concept has gained overwhelming acceptance among tourism authorities because destination image distinguishes tourism destinations from those of competitors, and has a significant impact on potential visitors' decision-making processes [33]. However, when investigating what constitutes state-of-the-art destination image building, the specialty literature and research concerning TOGC and UGC to articulate the destination image is still scarce [16,34,35].

Although the topic of tourism information in social media has received increasing attention [1,36] from researchers, none have so far focused on the combination of two different sources (i.e., social media TOGC and UGC). In an attempt to address this ambiguity, the present study investigates the dimensional model between social media content (i.e., TOGC and UGC) and image formation (i.e., cognitive image, affective image, and overall image) towards the selection of a sustainable destination. More specifically, this study answers the following research questions:

RQ 1. How does social media content (i.e., social media TOGC and UGC) formulate the destination image?

RQ 2. Does destination image (i.e., cognitive image, affective image, and overall image) influence travelers' intentions to select sustainable destinations?

This paper is organized as follows. The first part of the paper is aimed at examining the existing literature by highlighting the role of DMOs towards overall, fundamental concepts of social media content (i.e., TOGC and UGC), destination image (i.e., cognitive image, affective image, and overall image), and ultimately, the intention towards sustainable destinations. After this, the paper formulates a hypothetical association and framework of the key determinants. This is accompanied by the detailing of the research method. The results of the study are then discussed, followed by theoretical and practical implications. Finally, the study concludes with several limitations and further suggestions for future research. 


\section{Literature Review and Hypothesis Formulation}

\subsection{The Role of DMOs: Content, Image, and Destination Selection}

DMOs strategically lead to the primary function of destination marketing. The strategic use of information and communication technologies (ICTs) by DMOs has been a relevant topic in tourism research since the 1990s [37]. DMOs took this advantage and have started a direct interaction with tourists [11,38] through the use of social media [10,12]. These multimedia-enhanced websites and social media content enhance the experiences of consumers regarding the destinations without an actual visit [13].

However, numerous studies emphasize that different information sources influence the potential image formation process of visitors [39], and also highlight the robust effect on tourist intention [40]. This factor is identified as a "complex, relative, multiple, and dynamic concept" [41]. Therefore, it is crucial to recognize the role of DMOs' official websites and social media pages to construct destination images [14,42]. Researchers have examined the major role of the Internet and social media for the management and development of marketing strategies for DMOs $[43,44]$. The official website of the destination acts as the main tool to provide travelers with access to the required information about the destination. Thus, useful and reliable information forms the first impression of their perceived image $[45,46]$.

Researchers have documented the positive influence of DMO websites on image formation and the intention to visit the destination [47]. Besides enhanced social media engagement by DMOs, they also enhance consumers' positive effect on the destination image [48]. According to Chung, Lee, Lee, and Koo [49], the information quality of DMO websites indirectly influences traveler's intentions to visit a specific destination. The information is accessible on the DMO's official website, and it influences the development of cognitive and overall image formation [50]. Hays et al. [10] state that the use of social media among top national tourism organizations is still in an experimental stage. Regarding social media platforms, few studies have concentrated on the perceived destination image represented by the DMOs [7,17]; hence, it is necessary to explore DMOs' contributions towards content creation for destination choice purposes.

\subsection{Social-Media-Based Destination Content}

Social media has created an opportunity for DMOs and consumers alike, by being involved in the development of a destination image through an interactive content sharing approach. DMOs are using social media to build destination-brand identity and image [51]. On the other hand, the image can be shaped strongly by UGC through social media [52]. Therefore, DMOs are no longer the major controllers of the brands, given that consumers are also creating content and distributing it on social media [53]. Thus, the current study analyzes the weight that social media information sources exert in defining the destination image formation and influence traveler's intention to select a sustainable destination through tour operator generated content (TOGC) and user-generated content (UGC).

\subsubsection{Tour-Operator-Generated Content (TOGC)}

Before the internet revolution took place, the tourism industry was heavily dependent on tour operators and travel agents to disseminate information and sell their products or services. With the advent of Web 2.0, the tourism industry found a new way to eliminate intermediaries and reach consumers directly whilst reducing managerial costs [54]. Thus, direct virtual communication has boosted the tourism business with a high growth rate. Hence, the tourism industry has adopted this new interactive marketing tool for online marketing and communication with consumers [16]. Eventually, these new technologies motivated many tour operators to share travel content on social media in order to promote their service or business [55]. They have sparked and aroused the interest of travelers through informative presentations and persuasive content sharing on social media. Consequently, online sales conversion and travel information exploration via social media have become critical factors in the success of tour operators' tourism businesses [18]. Apart 
from an increased Web presence, social media has become an emerging travel information source for tour operators. They have aimed to influence targeted consumers by offering them the ability to compare prices, purchase tickets, and book accommodations through social media platforms. The online presence, quality, and functionality of the information have allowed tour operators to communicate directly with their potential customers [16].

Several researchers have stated that diverse sources of information influence the way in which travelers form their destination image [56,57]. According to Um and Crompton [58], the cognitive and affective image of a destination is formed not only by marketing information provided by tourism authorities but also by social influence in the form of recommendations from friends or family members. Tour operators are also concerned about the positive impact of recommendations and opinions on travelers' intentions. In this circumstance, tour operators would want to create credible travel information sources through the effective use of the interactive features of social media in order to strengthen their competitive advantage in the tourism industry [32]. By adopting various aspects, features, and functionalities of social media, tour operators can now virtually dispatch travel information, market their services, develop their relationships with targeted consumers, and most importantly, build a cognitive and affective destination image [6]. Thus, the following hypotheses were constructed:

Hypothesis 1a (H1a). TOGC has a positive influence on the cognitive destination image.

Hypothesis $\mathbf{1 b} \mathbf{( H 1 b ) . ~ T O G C ~ h a s ~ a ~ p o s i t i v e ~ i n f l u e n c e ~ o n ~ t h e ~ a f f e c t i v e ~ d e s t i n a t i o n ~ i m a g e . ~}$

\subsubsection{User-Generated Content (UGC)}

Choi, Lehto and Morrison [59] define User Generated Content (UGC) as:

... any form of content such as blogs, wikis, discussion forums, posts, chats, tweets, podcasting, pins, digital images, video, audio files, and other forms of media that were created by users of an online system or service, often made available via social media websites.

According to Kaplan and Haelein [60], UGC can be classified into six categories: (a) social networking sites, (b) blogs (e.g., Facebook, Twitter, WeChat), (c) collaborative projects (e.g., Wikipedia), (d) virtual social worlds (e.g., Second Life), (e) content communities (e.g., YouTube), (f) and virtual game worlds (e.g., Clash of Clan). The creation of and interaction with user-generated content are increasing in popularity, and have become an influential instrument for integrating the internet community [61]. UGC helps to express the interactions between travelers and marketers [62]. This opportunity encourages the society or peer group to share their opinions and experiences [63]. Most notably, numerous online digital platforms have served as sources of inspiration for travel information, influencing people to choose a sustainable destination $[64,65]$.

Travelers' interests have also indicated a growing trend in terms of reviewing comments and opinions that were relevant to the targeted destination or services. This could help to improve the image of a destination [15]. Potential travelers and consumers have also focused on other people's opinions about relevant destination products or services, in order to better manage and minimize risk and uncertainty [8]. In this regard, UGC is recognized as more important, dependable, enjoyable, and reliable than marketers' opinions and information [25]. Therefore, these sources of information affect the traveler's intention to select the travel destination [32]. UGC is regarded as one of the most powerful, dependable, and reliable channels of communication to influence the destination image [66]. Even so, there is still a lack of research regarding the unique effects of UGC on sustainable destination image formation [67]. In this regard, it is hypothesized that if travelers were aware of the online reviews and comments provided by UGC sources, they would consider other travelers' perceptions and suggestions as being useful in creating images of the destinations. Respectively, it is expected that UGC will have a significant impact on the destination's image. Hence, the following hypotheses were raised: 
Hypothesis 2a (H2a). UGC has a positive influence on the cognitive destination image.

Hypothesis $\mathbf{2 b} \mathbf{( H 2 b ) . ~ U G C ~ h a s ~ a ~ p o s i t i v e ~ i n f l u e n c e ~ o n ~ t h e ~ a f f e c t i v e ~ d e s t i n a t i o n ~ i m a g e . ~}$

\subsection{Destination Image Formation}

A destination image is a set of principles, thoughts, and perceptions that individuals have regarding a specific place or destination [68]. As a subjective concept, it is a complex fusion of products and attributes woven into a complete impression [69]. Numerous studies have inspected the destination image construction processes [68-70], and have supported the idea that destination image is a subjective notion shaped by the feelings and opinions of an individual. It has been documented that destination images influence tourists' attitudes and decision-making processes. According to the review article of Pike [71], destination image perceptions may affect a wide range of matters such as awareness, length of stay, frequency of visits, and even the perceived value of the destination. Accordingly, the image of a destination is a significant factor in determining its popularity with visitors, and is thus critical to the success of destination information marketing [72].

During the last few decades, traditional tourism information sources have been replaced by Internet-based travel websites and social media, which provide users with travel information and allow them to share their travel experiences in an interactive platform that influences destination image. Initial studies have recommended that destination image is more objective and cognitive. This factor was assessed by the perceived attributes which mirrored the destination with the emotional construct. The affective image denotes emotional reactions that reproduce the tourist's personal feelings about a specific destination [73]. Current studies [6,74] argue that images should also reflect tourists' actual visits or intentions to revisit, and recommendations of a destination. Thus, perceptions of destinations can be cognitive, affective, or conative through the information source, which has become vital for the authorities $[14,75,76]$.

Destination image and social media are emerging subjects in current tourism literature, and the relationship between these two topics has recently been investigated throughout some studies [15,76]. For instance, Kim et al. [6] documented that the tourism information quality provided by social media influences destination image formation through the 'cognitive-affective-conative' method. In the process of developing a destination image, social media information has affective and cognitive characteristics, which are closely linked to the affective image and the cognitive image [77]. Through storytelling on social media, information about the destination itself can influence the cognition of individuals; this can both stimulate brand co-creation and counter co-destruction. As a result, social media integration has become one of the most important methods for forming the image of a tourism destination [78].

As recommended in the tourism literature, the destination image plays a significant role among travelers in their destination choice processes and future visiting behaviors [18]. In other words, tourists who have a favorable destination image are more likely to intend to visit or to recommend the destination to others [25]. Although the topics of tourism information in social media and its role for various beliefs, as well as the topic of the behaviors of tourists, have received increasing attention from tourism researchers, still, little empirical evidence has been found regarding the relationship between the social media information source (i.e., TOGC and UGC) and the destination image formation. Moreover, this study also aims to examine the relationships between the cognitive and affective image to formulate the overall destination image.

\subsubsection{Cognitive Destination Image (CDI)}

The cognitive destination image discusses the beliefs and knowledge about the destination, and it is related to "the components of a destination that attract tourists, such as attractions to be seen, environment to be perceived (e.g., weather and public hygiene), and experiences to remember underlying in the cognitive structure of destination image" [79-81]. The cognitive image can be evaluated as the individual's acquaintance with and beliefs 
about the object, which reflects on the affective appraisals [59]. For example, social media video content increases users' knowledge about the destination, which will influence future feelings about their activities. Finally, cognitive and affective destination images may affect the users' actual behavior, which might be expressed during their visit. This behavior is based on the information and content displayed on a social media page [39]. In another piece of research, the cognitive component is represented by discernments of the service quality of the information provider, which is reflected as being a comparison between probability and the actual performance as perceived by travelers [24]. This image is identified as more descriptive, observable, and measurable. Baloglu and McCleary [17] have anticipated a destination image framework-comprising cognitive evaluation, affective evaluation, and an overall image - which is the result of the interaction of images. Based on this theoretical model, Baloglu and McCleary [17] delivered a piece of empirical evidence that the cognitive and affective images are interrelated, and that the effect is positively dependent on cognition, which is also the foundation of Gartner's [25] destination image formation theory. Consequently, the following hypotheses were formulated:

Hypothesis 3a (H3a). Cognitive destination image has a positive influence on the affective destination image.

Hypothesis $\mathbf{3 b} \mathbf{b} \mathbf{H} \mathbf{3} \mathbf{b})$. Cognitive destination image has a positive influence on the overall destination image.

\subsubsection{Affective Destination Image (ADI)}

An affective image states the emotions and feelings that a tourist holds about various features of the chosen destination. Moreover, several studies have recommended that the destination image should be measured by both cognitive (e.g., knowledge and ideas) and affective (e.g., feelings) aspects [79-81]. The affective component stimulates the comparable and conative components. According to Baloglu and McCleary [17], the cognitive and affective components are unified, and their effect is greatly dependent on cognition. After this, a study on online destination image also supported these findings when selecting the preferable destination [6]. Moreover, an empirical study has established that the affective image and overall image are consistent [67]. As regards the relationship between online information and cognitive image formation, a large amount of information-such as travel routes (e.g., 3 days in a city), local event calendars, and a list of must-eat restaurants-is presented on a DMO's website. These will support tourists to run through an affective image about what to do in the destination. However, a small amount of information (e.g., a short video clip or a photo of the destination) can sometimes have a huge impact on affective image formation [6]. Hence, the following hypothesis was suggested:

Hypothesis 4 (H4). Affective destination image has a positive influence on the overall destination image.

\subsubsection{Overall Destination Image (ODI)}

The overall image of a destination is designed through the intersection and connection of two types of destination images (e.g., cognitive and affective images). These destination images are formed from the suppliers, consumers, and third parties [76]. The overall destination image impacts both the destination selection process and the behavioral intentions of tourists [82]. The variables which are most frequently used to capture the behavioral intentions of tourists are related to the revisiting of the destination, and to their recommending to others through word of mouth (WoM) [15]. Positive WoM is a credible source of information for potential tourists [8]; what is more, it is particularly useful in the tourism industry, as it relies heavily on the opinions of previous travelers [67]. The previously-mentioned study explained that there are three main dimensions in the destination image (i.e., cognitive, affective, and conative destination image), which are found to be interconnected [6]. Another study also reported that the overall destination image impacts tourists' destination choice intention and the visiting of the destination, along 
with the willingness of tourists to recommend the destination to others [83]. Therefore, the following hypothesis was suggested:

Hypothesis 5 (H5). Overall destination image has a positive influence on the sustainable destination choice intention.

\subsection{Intention to Select Sustainable Destinations}

The concept of sustainability describes the expansion of the necessary resources used to manage sustainable long-term expansion without hindering the ability of future generations to meet their own needs [84]. This topic has been granted extensive attention, given that it is a critical issue in the tourism sector. According to the World Tourism Organization [85], the concept of "sustainable tourism is consistent with the theory of sustainable development". Three major components (i.e., financial, ecological, and sociocultural) need to be incorporated in order to develop sustainable tourism [86]. This concept satisfies the requirements of travelers and other stakeholders, as well as defending and developing prospects [87].

Some research $[88,89]$ has revealed the decision-making process for sustainable tourism. Studies $[90,91]$ have stated that the social networking site (SNS) has a large effect on tourist behavior. However, papers about the decision-making process of a sustainable destination choice and the effect of SNS on sustainable tourism are still rare. Hence, this study seeks to investigate how tourists' use of social media can affect their behavior, especially in sustainable destination selection. In order to fill this gap, this study uses the social media-based information source to understand travelers' destination image formation in order to select a sustainable destination.

According to Davis [92], intention reveals a decision that individuals have made about whether to carry out a behavior or not. Thus, intention predicts the actual usage of a specific ability which indicates a behavioral action [93]. Acceptance signifies an assurance or constant utilization of the technology over a given time-period. Numerous empirical studies have confirmed the intention-behavior relationship to be a worthy predictor of actual behavior [94-96]. These studies deemed that a continued manifestation of intention is necessary for the development of a sustainable destination choice. Consequently, intention designates a more stable mental status of consumers who have made use of the behavior manifested through social media. The intention of using the 'live' feature of social media as a travel information source is a cognitive representation of the user's destination image formation. Previous studies have confirmed the importance of intention for sustainable destination choice $[67,97]$. The proposed conceptual model is shown in Figure 1:

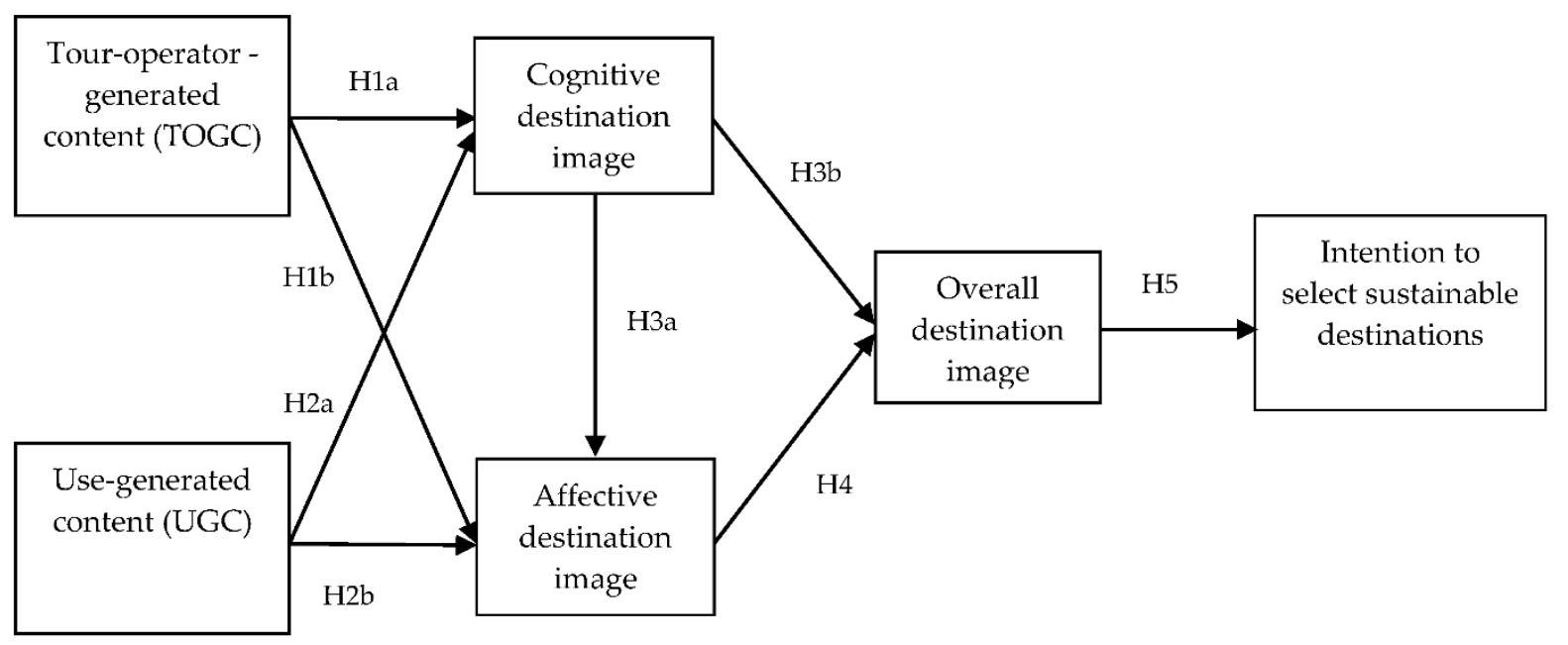

Figure 1. The conceptual model. 


\section{Research Methods}

\subsection{Instrument Development and Measures}

The cross-sectional quantitative research was conducted in the same manner as previous studies on social media and tourism $[67,98]$. The proposed model contains six constructs, namely: tour-operator-generated content (TOGC), user-generated content (UGC), cognitive destination image (CDI), affective destination image (ADI), overall destination image (ODI), and intention (INT). The questionnaire was designed based on the examination of the specific characteristics of online destination image formation. The survey questionnaire was composed of six parts: (i) a screening question, which was incorporated to confirm that the respondents are familiar with the social media destination image; (ii) a question about destination information source; (iii) questions or items on social media content (i.e., TOGC and UGC); (iv) questions or items on destination image (i.e., CDI, ADI, and ODI); (v) questions or items on intention towards sustainable destinations; and finally (vi) information about the demographic of respondents (i.e., gender, age, education, and monthly income). All of the measurement scales were evaluated on a 5-point Likert scale, ranging from " $1=$ strongly disagree" to " $5=$ strongly agree". Apart from this, in order to maintain the uniqueness of the measurements, the questionnaire was constructed in English, and afterward translated into Chinese [99]. The translated questionnaire was checked by three scholars with experience in empirical research, in order to verify the mutual understanding between the two languages. After the pilot test was conducted on a sample of 45 individuals in order to check the accuracy and precision of the questions, the questionnaire was then revised. Measurement items for all of the constructions were extracted from the relevant research to ensure a better validity of the content, and to fit the research context (see Appendix A).

For instance, TOGC (five-item scale) and UGC (five-item scale) were adapted and modified from Lai [100], Kim [6], and Joo [101]. The cognitive destination image (four-item scale) and affective destination image (four-item scale) were modified using research from Baloglu [68] and Almeida-Santana [102]. The overall destination image (four-item scale) was adapted from $\mathrm{Qu}$ [98] and Stylos [103]. Finally, the intention to select sustainable destinations (four-item scale) was adapted from Joo [101] and Mohaidin [104].

\subsection{Sample and Data Collection Procedures}

Chinese domestic travelers were chosen as the sample group of this study because of China's increasingly tourism-oriented economy according to official data, and because the Chinese tourism trade was valued at around RMB 5.7 trillion in 2019 [105]. The empirical data for this study were collected through a paper-based survey from five major shopping malls located in the Eastern province of Shanghai, China [106]. These locations were selected because of their high population density, with an approximate population of 26 million in 2019 [107]. Another element of interest is represented by the diversity of travelers. Thus, the different races, age brackets, history, and religions in Shanghai can be generalized to make up the population of China in this analysis.

The main field survey was carried out by using a non-probability convenience sampling technique [108]. The reason for choosing this technique is that this approach was more frequently used in research concerning tourism [109,110]. Moreover, the entire population is too large, and it would be inconvenient to use the independent random sampling technique. The data collection lasted one month, throughout June 2019, and was collected both during weekdays and weekends; the survey took around $15 \mathrm{~min}$ per person to complete. Before the distribution of the research questionnaire, the participants were asked to confirm their eligibility by answering if they are familiar with the concept of the social media destination image. Moreover, a short brief regarding the concept of sustainable destinations was offered in the introduction section of the questionnaire; the brief explained that "the sustainable destination is a long-term expansion of the tourism place towards future generations to meet their own need". Thus, a 'sustainable destination' is consistent with sustainable development, as the travelers are aware of the environmental conservation 
and recycling issue of a destination, and have a positive attitude about the local people, culture, and community of that destination.

A total of 500 questionnaires were distributed at the point of exit and entry of each shopping mall. Finally, 450 questionnaires were returned, and 425 valid questionnaires were used in this present statistical analysis. The rate of return and validity of the survey is $90 \%$ and $94.44 \%$ respectively. It is quite hard to develop generalized guidelines regarding sample size requirements for SEM [111]. Despite this, Kline [112] argued that the minimum sample size should be 200. On the other hand, a minimum of 10 cases per variable or item is required for the SEM analysis [113-115]. According to these suggestions, the current study, by considering a sample size of 425 , is sufficient when taking into account 26 scale items. Meanwhile, in order to test for possible non-response bias, an independent sample t-test was employed to compare the early respondents and late respondents [114]. Thus, it was determined that non-response bias is not a major concern in this research.

\subsection{Demographic Data}

Out of the 425 respondents (see Table 1), $55.8 \%$ of the tourists were male and $44.2 \%$ were female. Most of the respondents were aged 26-33 (45.6\%), followed by the 18-25 group $(30.4 \%)$ and the $34-41$ age group (18.4\%); $5.6 \%$ were aged 42 or above. Moreover, the majority of the respondents had a Postgraduate or master's degree $(68.5 \%)$, followed by those with an Undergraduate degree or less (30.1\%), and a Ph.D. or above $(1.4 \%)$. The respondents indicated their monthly income to be between 5001 and 7000 RMB (CNY) (31.1\%), followed by those earning between 7001 and $9000 \mathrm{RMB}(27.3 \%), 3001$ and $5000 \mathrm{RMB}$ $(27.2 \%)$, and finally, those earning $9001 \mathrm{RMB}$ or above (14.6\%). Lastly, the information sources used were: video-sharing sites (Youku, Tencent Video, Youtube) $(38.4 \%)$, social media platforms (WeChat, Tencent QQ, Facebook, Linkedin) (35.5\%), microblog sites (Sina Weibo, Twitter) (29.4\%), print media (Newspapers, Travel Magazines) $(16.2 \%)$, travel information (TripAdvisor) (14.7\%), photo sharing sites (Duotang, Flicker, Instagram) (7.6\%), broadcast media, FM Radio and television (3.9\%), and Wikipedia (0.5).

Table 1. Respondents' profile $(n=425)$.

\begin{tabular}{|c|c|c|c|}
\hline Characteristics & Category & Frequency & Percentage $(\%)$ \\
\hline \multirow[b]{2}{*}{ Gender } & Male & 237 & 55.8 \\
\hline & Female & 188 & 44.2 \\
\hline \multirow{4}{*}{ Age group } & 18-25 Years & 129 & 30.4 \\
\hline & 26-33 Years & 194 & 45.6 \\
\hline & 34-41 Years & 78 & 18.4 \\
\hline & 42 years or above & 24 & 5.6 \\
\hline \multirow{3}{*}{ Education level } & Undergraduate degree or less & 128 & 30.1 \\
\hline & Postgraduate or Master's degree & 291 & 68.5 \\
\hline & Ph.D. or above & 6 & 1.4 \\
\hline \multirow{4}{*}{ Monthly income level (Chinese RMB) } & $3001-5000$ & 115 & 27.1 \\
\hline & $5001-7000$ & 132 & 31.1 \\
\hline & $7001-9000$ & 116 & 27.3 \\
\hline & 9001 or above & 62 & 14.6 \\
\hline \multirow{9}{*}{ Information source } & $\begin{array}{c}\text { Social media } \\
\text { (WeChat, Tencent QQ, Facebook, LinkedIn) }\end{array}$ & 151 & 35.5 \\
\hline & $\begin{array}{c}\text { Print media } \\
\text { (Newspapers, Travel Magazines) }\end{array}$ & 69 & 16.2 \\
\hline & $\begin{array}{l}\text { Broadcast media } \\
\text { (FM Radio and Television) }\end{array}$ & 51 & 3.9 \\
\hline & Photo sharing site & & \\
\hline & (Duotang, Flicker, Instagram) & 65 & 7.6 \\
\hline & $\begin{array}{c}\text { Video sharing site } \\
\text { (Youku, Tencent Video, Youtube) }\end{array}$ & 69 & 38.4 \\
\hline & Micro blog site (Sina Weibo, Twitter) & 2 & 29.4 \\
\hline & Travel information (TripAdvisor) & 16 & 14.7 \\
\hline & Wikipedia & 2 & 0.5 \\
\hline
\end{tabular}




\section{Results}

\subsection{Data Analysis}

The data were analyzed using IBM SPSS V. 23.0 and AMOS 24.0 statistical software. Two-step data analyses were carried out in order to evaluate the measurement model and, after that, to test the hypotheses by fitting the structural model [113]. The Confirmatory Factor Analysis (CFA) was first conducted to test the overall fitness of the measurement model and to construct the reliability and validity of the constructs. Finally, structural equation modeling (SEM) and model fit indices were used to analyze the causal relationship of the constructs [115].

\subsection{Reliability and Validity Testing}

Considering that the user data was perceptual, and that a single source (i.e., face-toface survey) was applied for the data collection, common method bias might occur in this research, which could constitute a threat to the validity of the measurement items [116]. Hence, Harman's single factor test was employed to examine the common method bias. A total of $42.96 \%$ of the common variance was observed, which is lower than the $70 \%$ value indicated by Fuller et al. [117]. The results suggest that the common method bias was not a serious concern for the present research.

Confirmatory Factor Analysis (CFA) was used to empirically investigate the measurement model (see Table 2). For internal consistency, the values of the Cronbach's alpha $(\alpha)$ coefficient of every construct ranged from 0.868 to 0.909 . Consequently, the reliability of each construct was confirmed to be high, since they surpassed the recommended cut-off point of $0.7[118,119]$. The composite construct reliability $(\mathrm{CR})$ was also assessed to evaluate the multi-item scales [120]. The values fluctuated from 0.797 to 0.914 , which achieved the minimum requirement of 0.60 . The factor loadings attained a range from 0.846 to 0.905 , which is greater than the suggested value of 0.60 for the established items [121,122]. Furthermore, all of the average variance extracted (AVE) values ranged between 0.622 and 0.692 , exceeding the suggested cut-off point of 0.50 [113].

Table 2. Reliability and validity testing.

\begin{tabular}{|c|c|c|c|c|c|c|c|}
\hline Constructs & Items & Mean & SD & SFL & CR & AVE & Cronbach's Alpha $(\alpha)$ \\
\hline \multirow{5}{*}{ Tour-operator-generated content } & TOGC1 & 4.19 & 0.677 & 0.840 & 0.893 & 0.628 & 0.889 \\
\hline & TOGC2 & 4.25 & 0.678 & 0.734 & & & \\
\hline & TOGC3 & 4.18 & 0.668 & 0.908 & & & \\
\hline & TOGC4 & 4.21 & 0.681 & 0.757 & & & \\
\hline & TOGC5 & 4.20 & 0.650 & 0.706 & & & \\
\hline \multirow{5}{*}{ User-generated content } & UGC1 & 4.24 & 0.646 & 0.855 & 0.891 & 0.622 & 0.889 \\
\hline & UGC2 & 4.30 & 0.634 & 0.780 & & & \\
\hline & UGC3 & 4.28 & 0.626 & 0.801 & & & \\
\hline & UGC4 & 4.27 & 0.651 & 0.767 & & & \\
\hline & UGC5 & 4.28 & 0.653 & 0.737 & & & \\
\hline \multirow{4}{*}{ Cognitive destination image (CDI) } & CDI1 & 4.28 & 0.627 & 0.781 & 0.899 & 0.692 & 0.896 \\
\hline & CDI2 & 4.31 & 0.637 & 0.729 & & & \\
\hline & CDI3 & 4.32 & 0.661 & 0.897 & & & \\
\hline & CDI4 & 4.33 & 0.648 & 0.908 & & & \\
\hline \multirow{4}{*}{ Affective destination image (ADI) } & ADI1 & 4.30 & 0.627 & 0.736 & 0.905 & 0.648 & 0.868 \\
\hline & ADI2 & 4.28 & 0.638 & 0.820 & & & \\
\hline & ADI3 & 4.28 & 0.627 & 0.856 & & & \\
\hline & ADI4 & 4.28 & 0.655 & 0.757 & & & \\
\hline \multirow{4}{*}{ Overall destination image (ODI) } & ODI1 & 4.29 & 0.640 & 0.850 & 0.846 & 0.648 & 0.879 \\
\hline & ODI2 & 4.33 & 0.644 & 0.773 & & & \\
\hline & ODI3 & 4.26 & 0.655 & 0.790 & & & \\
\hline & ODI4 & 4.28 & 0.628 & 0.804 & & & \\
\hline \multirow{4}{*}{ Intention (INT) } & INT1 & 4.37 & 0.620 & 0.783 & 0.863 & 0.678 & 0.909 \\
\hline & INT2 & 4.35 & 0.623 & 0.801 & & & \\
\hline & INT3 & 4.38 & 0.640 & 0.884 & & & \\
\hline & INT4 & 4.39 & 0.649 & 0.909 & & & \\
\hline
\end{tabular}

$\mathrm{SD}$ = standard deviation; $\mathrm{SE}$ = standard error; $\mathrm{SFL}$ = standardized factor loading; $\mathrm{CR}$ = composite reliability; $\mathrm{AVE}=$ average variance extracted. 
The maximum likelihood method was used to test the validity of the proposed model when conducting the CFA. The findings demonstrate that the measurement model provided a good fit for the data $(\chi 2=550.155$; comparative fit index $(\mathrm{CFI})=0.965$; goodness of fit index $(\mathrm{GFI})=0.912$; incremental fit index $(\mathrm{IFI})=0.965$; Tucker-Lewis Index $(\mathrm{TLI})=0.960$ chisquare/degrees of freedom $(\chi 2 / \mathrm{df})=1.937$; probability level $(p)<0.00$, and root mean square error of approximation $($ RMSEA $)=0.047)$.

\subsection{Discriminant Validity}

The square roots of the AVE values and the correlations of constructs were compared in order to examine the discriminant validity of each construct. The threshold criterion was that the square roots of the AVE values should be larger than the correlations of each construct [121]. The AVE values of all constructs surpass the square correlations (0.432 to $0.679)$ and the square root of the AVE (0.78 to 0.83 ) for each construct [112]. The results in Table 3 show that the discriminant validity in this research was acceptable. Hence, all of the differences of the observed variables stated clearly by their latent variable were higher than the variations mentioned by their errors, indicating that the average explanatory power of each of the scales in the construct was sufficient.

Table 3. Results of the discriminant validity.

\begin{tabular}{|c|c|c|c|c|c|c|c|}
\hline & Constructs & TOGC & UGC & CDI & ADI & ODI & INT \\
\hline 1. & Tour-operator-generated content & 0.78 & & & & & \\
\hline 2. & User-generated content & $0.591^{* *}$ & 0.79 & & & & \\
\hline 3. & Cognitive destination image & $0.602^{* *}$ & $0.566^{* *}$ & 0.83 & & & \\
\hline 4. & Affective destination image & $0.610^{* *}$ & $0.673^{* *}$ & $0.569^{* *}$ & 0.80 & & \\
\hline 5. & Overall destination image & $0.477^{* *}$ & $0.503^{* *}$ & $0.489 * *$ & $0.513^{* *}$ & 0.80 & \\
\hline 6. & Intention & $0.448^{* *}$ & $0.510^{* *}$ & $0.432 * *$ & $0.469^{* *}$ & $0.679^{* *}$ & 0.82 \\
\hline
\end{tabular}

The diagonal values are AVE, and the off-diagonal values are inter-construct squared correlations, ${ }^{* *} p<0.01$.

\subsection{Structural Equation Modeling (SEM)}

The suggested relationship of the construct was statistically tested based on a covariance matrix. After all of the factors in the measurement model were reported to achieve the appropriate cutoff for the reliability and validity evaluations, the structural model study assumptions were further evaluated [121]. The structural model was analyzed using the maximum-likelihood estimation technique and the correlation matrix as the data input. The standardized regression coefficient $(\beta)$ and explanatory power $\left(R^{2}\right)$ can be seen in Figure 2 , where $R^{2}$ was greater than 0.2 , thus signifying a strong explanatory power [112].

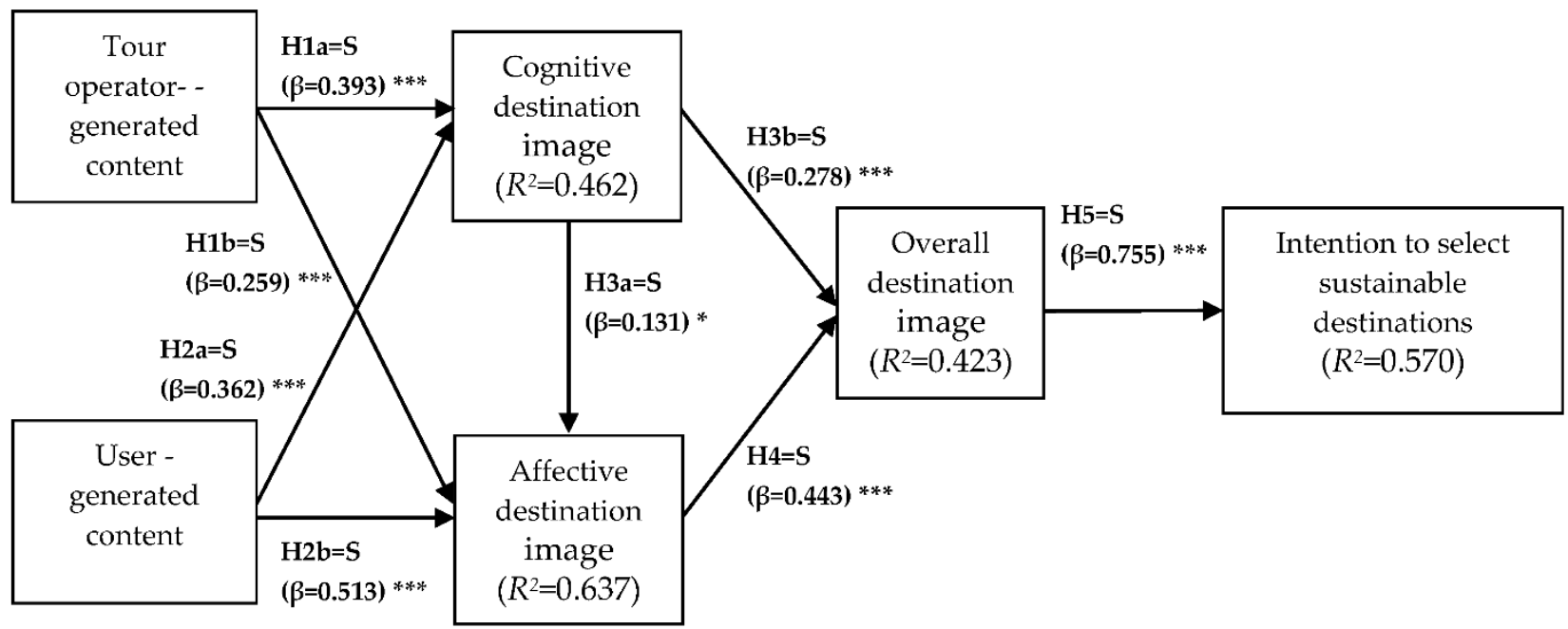

Figure 2. The results of testing the hypothetical model. ${ }^{* *} p<0.001,{ }^{*} p<0.05$. 
The overall fitness model specifies that chi-square $\left(X^{2}\right)=582.834$ at 290 degrees of freedom $(\mathrm{df}=290)$, and as such, it is significant at a probability level of $(p)=0.000$. The $\mathrm{X}^{2} / \mathrm{df}$ ratio of less than 5 (here 2.010) was used as the common decision rule of an acceptable overall fitness level of a model. The results show the fact that the theoretical framework presents an acceptable goodness of fit. Additionally, other indicators of goodness-of-fit are: the root mean square residual $(\mathrm{RMR})=0.024$; goodness of fit index $(\mathrm{GFI})=0.908$ (which is significant); adjusted goodness of fit index $(\mathrm{AGFI})=0.888$; normed fit index $(\mathrm{NFI})=0.927$; relative fit index $(\mathrm{RFI})=0.918$; incremental fit index $(\mathrm{IFI})=0.962$; Tucker-Lewis index $(\mathrm{TLI})=0.957$; comparative fit index $(\mathrm{CFI})=0.962$; root mean square error of approximation $($ RMSEA $)=0.049$ [83]. Within the overall model, the estimates of the structural coefficients provide the basis for testing the proposed hypotheses (see Figure 2).

\subsection{Hypotheses' Testing}

In order to determine the statistical significance of the hypothesized relationship, the explained variance $\left(R^{2}\right)$ between the dependent and mediating variables, the path coefficients $(\beta)$, and their significance levels (t-values) were assessed. The $R^{2}$ was greater than 0.2 for all of the endogenous constructions, thus indicating substantial explanatory power [112].

Table 4 illustrates the fact that seven proposed hypothesized paths are supported. First, the tour operator generated content (TOGC) was significantly related with both cognitive destination image $\left(\beta=0.393^{* * *}, p<0.001, \mathrm{t}=6.857\right)$ and affective destination image $\left(\beta=0.259^{* * *}, p<0.001, \mathrm{t}=4.578\right)$, supporting H1a and H1b. Moreover, the relationships between user-generated content (UGC), cognitive destination image $\left(\beta=0.362^{* * *}, p<0.001\right.$, $\mathrm{t}=6.238)$ and affective destination image $\left(\beta=0.513^{* * *}, p<0.001, \mathrm{t}=8.260\right)$, respectively, were found to be significant, supporting $\mathrm{H} 2 \mathrm{a}$ and $\mathrm{H} 2 \mathrm{~b}$ as well. Cognitive destination image was also significantly related with/to affective destination image $(\beta=0.131$ *, $p<0.05, \mathrm{t}=2.434)$ and overall destination image $\left(\beta=0.278^{* * *}, p<0.001, \mathrm{t}=4.779\right)$; thus, $\mathrm{H} 3 \mathrm{a}$ and $\mathrm{H} 3 \mathrm{~b}$ are supported. As expected, affective destination image was significantly associated with overall destination image $\left(\beta=0.443^{* * *}, p<0.001, \mathrm{t}=7.068\right)$, which strongly supports H4. Similar results were obtained for the hypothesis by providing a highly significant association between overall destination image and the intention for the selection of a sustainable destination, i.e., $\mathrm{H} 5$ is supported $\left(\beta=0.755^{* * *}, p<0.001, \mathrm{t}=14.124\right)$. Hence, hypotheses 1 to 5 are statistically validated, indicating that all of the variables of social media TOGC and UGC are significantly related to the process of image destination formation of/by travelers and influence their sustainable destination choice intention.

Table 4. Summary of the hypotheses' testing results.

\begin{tabular}{ccccc}
\hline Hypothesis & Path & Standardized Regression Coefficient $(\boldsymbol{\beta})$ & $\begin{array}{c}\text { C. } \text { R. } \\
(=t \text { Value })\end{array}$ & Decision \\
\hline H1a & TOGC $\rightarrow$ CDI & 0.393 & $6.857^{* * *}$ & Supported \\
H1b & TOGC $\rightarrow$ AFI & 0.259 & $4.578^{* * *}$ & Supported \\
H2a & UGC $\rightarrow$ CDI & 0.362 & $6.238^{* * *}$ & Supported \\
H2b & UGC $\rightarrow$ ADI & 0.513 & $8.260^{* * *}$ & Supported \\
H3a & CDI $\rightarrow$ ADI & 0.131 & $2.434^{*}$ & Supported \\
H3b & CDI $\rightarrow$ ODI & 0.278 & $4.779^{* * *}$ & Supported \\
H4a & ADI $\rightarrow$ ODI & 0.443 & $7.068^{* * *}$ & Supported \\
H5 & ODI $\rightarrow$ INT & 0.755 & $14.124^{* * *}$ & Supported \\
\hline
\end{tabular}

\section{Discussion}

Social media has become an important source of information for the understanding of the concept of a sustainable process. In general, the issue of sustainability is well addressed in social networking sites, which are mainly linked to the sustainable destination choice intention. For more than a decade, sustainable destination choice behavior was considered an ideal approach for the efficient management of travel destinations. The sustainable 
utilization of tourism resources, comprising but not limited to accommodation, physical infrastructure, transportation, and awareness-raising for travelers, remains a challenge for the DMOs. Thus, social media can be used by DMOs to obtain information about their needs as consumers, and to create a relationship between the content makers and consumers at an insignificant cost. At this point, the appearance of social media-based tourism content is changing dramatically [123]. However, social media content and the formulation of destination image towards sustainable destinations have not been documented. Therefore, the current research aims to examine the influence of tour-operator-generated content (TOGC) and user-generated content (UGC) to formulate the destination image, and to ascertain how it works on the selection of a sustainable destination. Thus, in order to achieve this objective, the present study proposed a conceptual model to explain the role of cognitive, affective, and overall destination image as three mediators.

Next, this study has detailed results. Firstly, two independent variables, TOGC and UGC, found a positive and significant association with the cognitive and affective destination image. Hence, hypotheses $\mathrm{H} 1 \mathrm{a}, \mathrm{H} 1 \mathrm{~b}, \mathrm{H} 2 \mathrm{a}$, and $\mathrm{H} 2 \mathrm{~b}$ are supported. These findings are similar to the previous investigation based on social media information sources $[6,77,124]$. Secondly, cognitive destination image has also shown a positive and significant connection with an affective destination image and overall destination image, which supports $\mathrm{H} 3 \mathrm{a}$ and $\mathrm{H} 3 \mathrm{~b}$. These results are almost similar to prior research on destination image formation [6,77]. Thirdly, affective destination image was also shown to have a positive significant association with overall destination image, which supports H4. This is similar to previous findings $[67,125]$. Finally, the overall destination image has a positive and significant relationship with the intention to select sustainable destinations, thus supporting H5. Based on the full model (see Figure 2), the results revealed that all eight hypothetical relationships were supported empirically. The finding corroborates the study on social media information sources and destination image formation by travelers. The analysis results show that social media is significantly effective to formulate destination image, and thus influences the selection of sustainable destinations. The research findings also showed that the satisfactory explanatory power of CDI is $46 \%$, i.e., $\mathrm{R}^{2}=0.462$, ADI is $64 \%$, i.e., $\mathrm{R}^{2}=0.637$, ODI is $42 \%$, i.e., $\mathrm{R}^{2}=0.423$; and INT is $57 \%$, i.e., $\mathrm{R}^{2}=0.570$. Therefore, these results indicate that all of the variables were significantly related to the respondents' intention to select sustainable destinations.

The findings of this research support the key argument that the information source plays a vital role in online destination image formation [15,83]. According to the findings, all of the underlying factors are affected by destination image formation through two types of social media-based information. First of all, travel information indications, the relevance to enhance sustainable awareness, and continuous updates affect the destination image formation. As regards aspects of relevance, travelers are mostly influenced by the appropriateness of the information. The reason for which this occurs is the fact that a huge amount of information posted on social media tends to gain momentum and importance, and as such, the accessibility of the relevant information is important. Therefore, it might be more significant for information seekers to identify relevant sources of information, sources that are to be tailored to a sustainable aspect of the destination. Besides this, the results suggest that travelers' destination image formation is more significantly associated with information usefulness, and that it (usefulness of information) influences the sustainable destination selecting intention. The overall destination image process of cognitive and affective image formation is the reason for which this occurs. A possible cause of this finding could be that information source accuracy and attractiveness are identified as being the major factors which are influential for the building of a destination image [126]. This finding suggests that it is essential to recognize that the role of information provided by tour operators is highly motivated by the usefulness and accuracy necessary to build an overall destination image. According to the findings, social media information sources have the potential to influence sustainable destination selection by travelers. Admitting to the formulation of the hypotheses, user-generated content was found to strongly influence 
cognitive, affective, and overall destination image formation. This is similar to previous studies which contended that user-generated content is more reliable than a travel agency or professional tourism website [127].

\section{Conclusions}

This study gives a new perspective into social media TOGC and UGC, and their influence on destination image formation and sustainable destination selection. The results of this study suggest that TOGC and UGC are useful for research on the topic of the destination choice intention of individuals, as mediated by the cognitive, affective, and overall destination image. The suggested research model could help improve and expand knowledge and studies on tourism. The findings will foster curiosity in future studies, which will lead researchers to determine other factors which may contribute to sustainable destination selection; what is more, these findings will also lead to more efficient social media promotional activities. Apart from this, the conceptual framework might be reformed with various aspects in order to better evaluate the destination choice intention of travelers.

\subsection{Implications}

The present study supports previous assertions that social media information sources influence travelers' choice of a sustainable destination, and confirms the roles of TOGC, UGC, and DI, which are of interest due to a relative neglect of prior studies in investigating the integrated causal relationships between TOGC and UGC, as well as related constructs. This study proposes different alternatives to conceptualizing the relationships between TOGC, UGC, cognitive and affective images, overall destination image, and intention. The empirical results support the conceptual model, and conclude that TOGC and UGC represent an important antecedent to destination image formation, which in turn has a mediating impact on sustainable destination choice intentions. This study has made significant contributions to academic research and tourism businesses by understanding how the TOGC and UGC - through their presence on social media-formulate cognitive, affective, and overall destination image, and influence travelers' intentions towards a sustainable destination choice. The implications of the contributions are presented below.

\subsubsection{Theoretical Implications}

The research on user-generated content and destination image is evolving from the initial stages, which were mostly limited to analyzing textual reviews. In contrast, our research attempts to offer insights on the influence of user-generated content and touroperator-generated content by comparing them to a social media destination image. The findings suggest that the presentation format, in particular the UGC, can assist as a significant stimulus in influencing online destination image, even more so than the TOGC. Thus, this research advances the current understandings of the effects of UGC and TOGC in several significant ways.

Firstly, this study provides an empirical method focused on social media TOGC and UGC in connection to the selection of a sustainable destination. Moreover, its conceptual contribution also consists of an attempt to fill a gap regarding social media destination image formation. The proposed model combines the TOGC and UGC, and offers a significant framework used to examine the cognitive, affective, and overall destination image formation of travelers, and contributes to the process of intention selection for sustainable destinations.

Secondly, the social media-based cognitive, affective, and overall destination image confirmed the initial model for future academic research purposes. Destination image is crucial in the tourist decision-making process, and it plays a key role in destination marketing. Thus, the hypothetical results of this study are valuable in understanding the sustainable destination selection process. The influential aspects of TOGC and UGC were mediated by cognitive, affective, and overall destination image to strengthen the traveler's sustainable destination selection intention. Thirdly, this is the initial attempt to 
understand the association between destination image and intention; thus, the findings will provide meaningful insights for future research. Moreover, the findings will also enable the enforcement of marketing approaches for tourism destinations, and will thus improve the sustainable destination marketing approach.

\subsubsection{Managerial Implications}

This study provided an in-depth understanding of how TOGC and UGC create opportunities for the marketing organization, and makes recommendations on how travel service providers could capitalize on these trends and use this for the benefit of their businesses. Destination promoters need to strategically manage their destination as a 'product' in order to achieve uniqueness and competitiveness in the eyes of potential travelers [128]. They need to recognize the factors influencing the attitudes of potential travelers toward the destinations. This study thus encourages destination marketers to consider destination information factors as a key antecedent to the attitudes of travelers. A tourism destination can be represented as a brand composed of intangible and tangible features. Thus, marketers need to manage destination branding by focusing more on assessing and enhancing both the cognitive and affective image of the destination through information sources.

From this empirical study, destination marketing organizations (DMOs) and private tour operators will be interested in the implications regarding the ways in which to gain a stronger and enhanced understanding of the role of TOGC and UGC in the behavior of destination choice. For example, in order to recognize the attitudes manifested by travelers toward a sustainable destination, marketers can place more emphasis on the presence of social media information to enhance sustainable destination image. They can quantify the notion of the cognitive image by using the physical features of the destination (e.g., natural beauty, beaches, activity, theme parks, cultural festivals, shopping opportunity, friendly locals), whereas for the affective image, they can use attribute descriptors, such as 'modern', 'exciting', 'appealing', 'unique', 'trustworthy', 'up-to-date', 'competent', 'imaginative', 'sincere', 'honest', 'cheerful', 'authentic', and 'conservative' [129,130]. However, without the knowledge of how information factors influence the travel plans of travelers, the marketing efforts of DMOs will not be as effective as initially thought. In other words, DMOs need to know how travelers recognize and assess the underlying factors of TOGC and UGC, and-based on the responses of travelers-they can understand what actions need to be taken through the use of social media marketing policy. As UGC refers to uploading and referencing influential content, this study provides important directions to DMOs or tour operators regarding the ways in which to efficiently utilize UGC factors to develop social media promotional activities.

The importance of UGC is increasing, and has enormous implications for social media services, such as accommodation, transportation, and food, etc. The practical contributions made by this study could be beneficial to national tourism organizations and tourism service providers in numerous ways, e.g., by improving the marketing efforts of national tourism organizations (NTO's), DMOs, and private tour operators [131]. Tourism marketers should carefully consider UGC content when designing their social media promotional activity and redesigning their official website. Under these circumstances, DMOs and tour operators should use UGC as a referee marketing policy, and should encourage travel reviewers to provide more accurate opinions from time to time. For instance, travel content writers or reviewers could share their travel experience by using specific details, such as the date, time, and location. Such details could in turn influence potential travelers to make a selection of the destination faster. DMOs and tour operators could also provide basic information about contributing better opinions, advice, comments to the readers/users of the tourism services (i.e., accommodation, food, shopping, attractions, activity, etc.). This will help improve the travel information competitiveness and the quality of the content. 


\subsection{Limitations and Future Work}

This research was subject to some limitations, which should be considered for further research. First, we did not take into account the opinions of users of particular social media platforms (i.e., Facebook, Instagram, WeChat) towards the image formation. Second, we did not focus on the significant activities on social media (i.e., photos, video, storyboard, live streaming, graphic presentation) which influence travelers to select sustainable destinations. Third, in order to measure the sustainable destinations, we did not propose the sustainability construct in the conceptual model; as such, future studies should therefore investigate these issues. Fourth, the aspects involved in the study were investigated only at one point in time. Additional research should use pre- and post-response evaluations to validate the proposed framework. Fifth, another limitation was the selection of samples and locations, for which the results may lack the ability to be applied to a broader spectrum of society. Sixth, the convenience sampling technique was another limitation which may impede the general applicability of the research findings. Finally, future research might want to make use of the focus group discussion (FGD) or in-depth interviews in order to identify the factors affecting the choice of the sustainable destination.

Author Contributions: The authors' contributions were as follows. Conceptualization: M.T.S. and F.S.; Methodology: M.T.S. and F.S.; Software, M.T.S.; Validation, M.T.S., and F.S.; Formal analysis, M.T.S., F.S. and A.B.; Investigation: F.S. and K.X.; Resources: K.X.; Data curation: F.S. and M.T.S.; Writing-original draft preparation: M.T.S. and F.S. Writing-review and editing: A.B., D.G. and K.X.; Project administration and supervision: K.X.; M.T.S. and F.S. equally contributed as the first authors to this work. All authors have read and agreed to the published version of the manuscript.

Funding: This article was partially supported through the project 'SmartDoct-High-quality programs for doctoral students and postdoctoral researchers of the University of Oradea for increasing the relevance of research and innovation in the context of the regional economy', ID/project code: 123008, co-financed by the European Social Fund through The Human Capital Operational Program 2014-2020.

Institutional Review Board Statement: Not applicable.

Informed Consent Statement: Not applicable.

Data Availability Statement: Data are available upon request from researchers to the corresponding author: tipusultan_ctg@sjtu.edu.cn.

Conflicts of Interest: The authors declare no conflict of interest.

\section{Appendix A. Constructs and Scale Items}

Table A1. Constructs and scale items.

\begin{tabular}{|c|c|c|}
\hline Latent Variable & Item Text & Source of Adoption \\
\hline Tour-operator generated content & $\begin{array}{l}\text { TOGC1: Tour-operator-generated content is relevant towards the } \\
\text { sustainable destination. } \\
\text { TOGC2: Tour-operator-generated content is up-to-date about the } \\
\text { sustainable destination. } \\
\text { TOGC3: Tour-operator-generated content is authentic towards a } \\
\text { sustainable destination. } \\
\text { TOGC4: Tour-operator-generated content can help to raise environmental } \\
\text { awareness of the sustainable destination. } \\
\text { TOGC5: Tour-operator-generated content can increase the awareness of the } \\
\text { negative impacts on the local environment. }\end{array}$ & {$[6,100,101]$} \\
\hline User-generated content & $\begin{array}{l}\text { UGC1: User-generated content is relevant to a sustainable destination. } \\
\text { UGC2: User-generated content is continuously up-to-date. } \\
\text { UGC3: User-generated content is authentic. } \\
\text { UGC4: User-generated content is accurate. } \\
\text { UGC5: User-generated content is effective towards a } \\
\text { sustainable destination. }\end{array}$ & {$[6,100,101]$} \\
\hline
\end{tabular}


Table A1. Cont.

\begin{tabular}{|c|c|c|}
\hline Latent Variable & Item Text & Source of Adoption \\
\hline Cognitive destination image & $\begin{array}{l}\text { What is your social media-based cognitive destination image about a } \\
\text { sustainable destination? } \\
\text { CDI1: The sustainable destination will be offering an } \\
\text { eco-friendly environment. } \\
\text { natural heritage. } \\
\text { CDI3: The sustainable destination will be offering a conservational } \\
\text { CDI4: The sustainable destination will be offering } \\
\text { eco-friendly accommodation. }\end{array}$ & {$[68,102]$} \\
\hline Affective destination image & $\begin{array}{l}\text { What is your social media-based affective destination image about a } \\
\text { sustainable destination? } \\
\text { ADI1: The destination will be sustainably arousing. } \\
\text { ADI2: The destination will be sustainably pleasant. } \\
\text { ADI3: The destination will be sustainably exciting. } \\
\text { ADI4: The destination will be sustainably relaxing. }\end{array}$ & {$[68,102]$} \\
\hline Overall destination image & $\begin{array}{l}\text { What is your social media-based overall destination image about the } \\
\text { sustainable destination? } \\
\text { ODI1: The destination will be environmentally favorable. } \\
\text { ODI2: The destination will be very positive towards travelers. } \\
\text { ODI3: The destination will be very satisfactory to the community. } \\
\text { ODI4: The sustainable destination will be a suitable vacation choice. }\end{array}$ & {$[98,103]$} \\
\hline Intention & $\begin{array}{l}\text { INT1: I am willing to pursue environmentally sustainable activities (e.g., } \\
\text { energy conservation, recycling) in the future. } \\
\text { INT2: I plan to support environmental initiatives about } \\
\text { sustainable destination. } \\
\text { INT3: I will make an effort to promote a sustainable approach towards } \\
\text { the destination. } \\
\text { INT4: I plan to play a part in reducing harm to the environment in the } \\
\text { future at a sustainable destination. }\end{array}$ & {$[101,104]$} \\
\hline
\end{tabular}

\section{References}

1. Tham, A.; Croy, G.; Mair, J. Social Media in Destination Choice: Distinctive Electronic Word-of-Mouth Dimensions. J. Travel Tour. Mark. 2013, 3, 144-155. [CrossRef]

2. Li, R.; Suh, A. Factors Influencing Information credibility on Social Media Platforms: Evidence from Facebook Pages. Procedia Comput. Sci. 2015, 72, 314-328. [CrossRef]

3. Zha, X.; Yang, H.; Yan, Y.; Liu, K.; Huang, C. Exploring the effect of social media information quality, source credibility and reputation on informational fit-to-task: Moderating role of focused immersion. Comput. Hum. Behav. 2018, 79, 227-237. [CrossRef]

4. Shuang, Y. Effects of information quality and source credibility on EWOM adoption in context of virtual community. In Proceedings of the 2013 International Conference on Management Science and Engineering 20th Annual Conference Proceedings, Harbin, China, 17-19 July 2013; pp. 194-200.

5. Huertas, A. How live videos and stories in social media influence tourist opinions and behaviour. Inf. Technol. Tour. 2018, 19, 1-28. [CrossRef]

6. Kim, S.; Young, K.; Il, S.; Yang, S. Effects of tourism information quality in social media on destination image formation: The case of Sina Weibo. Inf. Manag. 2017, 54, 687-702. [CrossRef]

7. Molinillo, S.; Liébana-Cabanillas, F.; Anaya-Sánchez, R.; Buhalis, D. DMO online platforms: Image and intention to visit. Tour. Manag. 2018, 65, 116-130. [CrossRef]

8. Gurung, D.J.; Goswami, C. User Generated Content on Sikkim as an Image Formation Agent: A Content Analysis of Travel Blogs. Int. J. Hosp. Tour. Syst. 2017, 10, 47-57.

9. Diwanji, V.S.; Cortese, J. Contrasting user generated videos versus brand generated videos in ecommerce. J. Retail. Consum. Serv. 2020, 54, 102024. [CrossRef]

10. Hays, S.; Page, S.J.; Buhalis, D. Social media as a destination marketing tool: Its use by national tourism organisations. Curr. Issues Tour. 2013, 16, 211-239. [CrossRef]

11. Pike, S.; Page, S.J. Destination Marketing Organizations and destination marketing: A narrative analysis of the literature. Tour. Manag. 2014, 41, 202-227. [CrossRef]

12. Mariani, M.M.; Di, M.; Mura, M. Facebook as a destination marketing tool: Evidence from Italian regional Destination Management Organizations. Tour. Manag. 2016, 54, 321-343. [CrossRef]

13. Cho, Y.H.; Wang, Y.; Fesenmaier, D.R. Searching for experiences: The web-based virtual tour in tourism marketing. J. Travel Tour. Mark. 2002, 12, 1-17. [CrossRef] 
14. Költringer, C.; Dickinger, A. Analyzing destination branding and image from online sources: A web content mining approach. J. Bus. Res. 2015, 68, 1836-1843. [CrossRef]

15. de las Heras-Pedrosa, C.; Millan-Celis, E.; Iglesias-Sánchez, P.P.; Jambrino-Maldonado, C. Importance of social media in the image formation of tourist destinations from the stakeholders' perspective. Sustainability 2020, 12, 4092. [CrossRef]

16. Marine-Roig, E.; Ferrer-Rosell, B. Measuring the gap between projected and perceived destination images of Catalonia using compositional analysis. Tour. Manag. 2018, 68, 236-249. [CrossRef]

17. Parent, M.; Plangger, K.; Bal, A. The new WTP: Willingness to participate. Bus. Horiz. 2011, 54, 219-229. [CrossRef]

18. Mehmood, S.; Liang, C.; Gu, D. Heritage Image and Attitudes toward a Heritage Site: Do They Really Mediate the Relationship between User-Generated Content and Travel Intentions toward a Heritage Site? Sustainability 2018, 10, 4403. [CrossRef]

19. Xiang, Z.; Gretzel, U. Role of social media in online travel information search. Tour. Manag. 2010, 31, 179-188. [CrossRef]

20. Mangold, W.G.; Faulds, D.J. Social media: The new hybrid element of the promotion mix. Bus. Horiz. 2009, 52, 357-365. [CrossRef]

21. Kietzmann, J.H.; Hermkens, K.; McCarthy, I.P.; Silvestre, B.S. Social media? Get serious! Understanding the functional building blocks of social media. Bus. Horiz. 2011, 54, 241-251. [CrossRef]

22. Llodra-Riera, I.; Martínez-Ruiz, M.P.; Jiménez-Zarco, A.I.; Izquierdo-Yusta, A. Assessing the influence of social media on tourists' motivations and image formation of a destination. Int. J. Qual. Serv. Sci. 2015, 7, 458-482. [CrossRef]

23. Cooper, C.; Fletcher, J.; Gilbert, D.; Wanhill, S. Tourism: Principles and Practice; Pitman Publishing: London, UK, 1993.

24. Lee, C.K.; Lee, Y.K.; Lee, B.K. Korea's Destination Image Formed by the 2002 World Cup. Ann. Tour. Res. 2005, 32, 839-858. [CrossRef]

25. Alcázar, M. del C.H.; Departamento; Piñero, M.S.; Maya, S.R. de The effect of user-generated content on tourist behavior: The mediating role of destination image. Tour. Manag. Stud. 2014, 10, 158-164.

26. Kim, Y.; Hall, H.; Kim, M.; Hall, H.; Kim, K.; Hall, H. Factors Influencing the Adoption of Social Media in the Perspective of Information Needs. In Proceedings of the iConference, University of Illinois at Urbana-Champaign, Champaign, IL, USA, 2-6 February 2010.

27. Liu, Y.; Segev, S.; Villar, M.E. Comparing two mechanisms for green consumption: Cognitive-affect behavior vs theory of reasoned action. J. Consum. Mark. 2017, 34, 442-454. [CrossRef]

28. Seddighi, H.R.; Theocharous, A.L. A model of tourism destination choice: A theoretical and empirical analysis. Tour. Manag. 2002, 23, 475-487. [CrossRef]

29. Gretzel, U.; Fesenmaier, D.R.; Leary, J.O. The transformation of consumer behaviour. In Tourism Business Frontiers; Routledge: London, UK, 2006; pp. 7-16.

30. Gretzel, U. Consumer Generated Content-Trends and Implications for Branding. e-Rev. Tour. Res. 2006, 4, 9-11.

31. De Cuypere, E.; De Turck, K.; Fiems, D. Opinion spreading of a tourism-related topic in an online travel forum. In Proceedings of the TTRA 2014 International Conference, Brugge, Belgium, 18-20 June 2014.

32. Stepchenkova, S.; Mills, J.E.; Mills, J.E. Destination Image: A Meta-Analysis of 2000-2007 Research. J. Hosp. Mark. Manag. 2010, 16, 575-609. [CrossRef]

33. Baloglu, S.; Brinberg, D. Affective Images of Tourism Destinations. J. Travel Res. 1997, 35, 11-15. [CrossRef]

34. Lian, T.; Yu, C. Impacts of online images of a tourist destination on tourist travel decision. Tour. Geogr. 2019, 21, 635-664. [CrossRef]

35. Mak, A.H.N. Online destination image: Comparing national tourism organisation's and tourists' perspectives. Tour. Manag. 2017, 60, 280-297. [CrossRef]

36. Jalilvand, M.R.; Samiei, N. The impact of electronic word of mouth on a tourism destination choice: Testing the theory of planned behavior (TPB). Internet Res. 2012, 22, 591-612. [CrossRef]

37. Buhalis, D. Strategic use of information technologies in the tourism industry. Tour. Manag. 1998, 19, 409-421. [CrossRef]

38. Buhalis, D.; Law, R. Progress in information technology and tourism management: 20 years on and 10 years after the Internet-The state of eTourism research. Tour. Manag. 2008, 29, 609-623. [CrossRef]

39. Beerli, A.; Martín, J.D. Tourists' characteristics and the perceived image of tourist destinations: A quantitative analysis-A case study of Lanzarote, Spain. Tour. Manag. 2004, 25, 623-636. [CrossRef]

40. Tan, W.K.; Wu, C.E. An investigation of the relationships among destination familiarity, destination image and future visit intention. J. Destin. Mark. Manag. 2016, 5, 214-226. [CrossRef]

41. Gallarza, M.G.; Saura, I.G.; García, H.C. Destination image. Ann. Tour. Res. 2002, 29, 56-78. [CrossRef]

42. Kock, F.; Josiassen, A.; Assaf, A.G. Advancing destination image: The destination content model. Ann. Tour. Res. 2016, 61, 28-44. [CrossRef]

43. Buhalis, D. Marketing the competitive destination of the future. Tour. Manag. 2000, 21, 97-116. [CrossRef]

44. Gretzel, U.; Fesenmaier, D.R.; Formica, S.; O'Leary, J.T. Searching for the future: Challenges faced by destination marketing organizations. J. Travel Res. 2006, 45, 116-126. [CrossRef]

45. Cho, M.H.; Sung, H.H. Travel Destination Websites: Cross-Cultural Effects on Perceived Information Value and Performance Evaluation. J. Travel Tour. Mark. 2012, 29, 221-241. [CrossRef]

46. Luna-Nevarez, C.; Hyman, M.R. Common practices in destination website design. J. Destin. Mark. Manag. 2012, 1, 94-106. [CrossRef] 
47. Tigre Moura, F.; Gnoth, J.; Deans, K.R. Localizing Cultural Values on Tourism Destination Websites: The Effects on Users' Willingness to Travel and Destination Image. J. Travel Res. 2015, 54, 528-542. [CrossRef]

48. Davidson, R.; Keup, M. The Use of Web 2.0 as a Marketing Tool by European Convention Bureaux. Scand. J. Hosp. Tour. 2014, 14, 234-254. [CrossRef]

49. Chung, N.; Lee, H.; Lee, S.J.; Koo, C. The influence of tourism website on tourists' behavior to determine destination selection: A case study of creative economy in Korea. Technol. Forecast. Soc. Chang. 2015, 96, 130-143. [CrossRef]

50. Jeong, C.; Holland, S.; Jun, S.H.; Gibson, H. Enhancing destination image through travel website information. Int. J. Tour. Res. 2012, 14, 16-27. [CrossRef]

51. Mariani, M.M.; Mura, M.; Di, M. The determinants of Facebook social engagement for national tourism organizations' Facebook pages: A quantitative approach. J. Destin. Mark. Manag. 2018, 8, 312-325. [CrossRef]

52. Lim, Y.; Chung, Y.; Weaver, P.A. The impact of social media on destination branding: Consumer-generated videos versus destination marketer-generated videos. J. Vacat. Mark. 2012, 18, 197-206. [CrossRef]

53. Llodra-Riera, I.; Martínez-Ruiz, M.P.; Jimenez-Zarco, A.I.; Izquierdo-Yusta, A. A multidimensional analysis of the information sources construct and its relevance for destination image formation. Tour. Manag. 2015, 48, 319-328. [CrossRef]

54. Buhalis, D.; Licata, M.C. The future eTourism intermediaries. Tour. Manag. 2002, 23, 207-220. [CrossRef]

55. Marin-Pantelescu, A.; Tăchiciu, L.; Căpuşneanu, S.; Topor, D.I. Role of tour operators and travel agencies in promoting sustainable tourism. Amfiteatru Econ. 2019, 21, 500-516. [CrossRef]

56. Tsiakali, K. User-generated-content versus marketing-generated-content: Personality and content influence on traveler's behavior. J. Hosp. Mark. Manag. 2018, 27, 946-972. [CrossRef]

57. Senders, A.; Govers, R.; Neuts, B. Social Media Affecting Tour Operators' Customer Loyalty. J. Travel Tour. Mark. 2013, 30, 41-57. [CrossRef]

58. Um, S.; Crompton, J.L. Attitude Destination in Tourism Destination Choice. Ann. Tour. Res. 1990, 17, 432-448. [CrossRef]

59. Choi, S.; Lehto, X.Y.; Morrison, A.M. Destination image representation on the web: Content analysis of Macau travel related websites. Tour. Manag. 2007, 28, 118-129. [CrossRef]

60. Kaplan, A.M.; Haenlein, M. Users of the world, unite! The challenges and opportunities of Social Media. Bus. Horiz. 2010, 53, 59-68. [CrossRef]

61. Mohammad, J.; Quoquab, F.; Thurasamy, R.; Alolayyan, M.N. The Effect of User-Generated Content Quality on Brand Engagement: The Mediating Role of Functional and Emotional Values. J. Electron. Commer. Res. 2020, 21, 39-55.

62. Daugherty, T.; Eastin, M.S.; Bright, L. Exploring Consumer Motivations for Creating User-Generated Content. J. Interact. Advert. 2008, 8, 16-25. [CrossRef]

63. Blackshaw, P.; Nazzare, M. Consumer Generated Media (CGM) 101: Word of Mouth in the Age of the Web-Fortified Consumer; Nielsen Buzz Metrics.: New York, NY, USA, 2006

64. Han, W.; McCabe, S.; Wang, Y.; Chong, A.Y.L. Evaluating user-generated content in social media: An effective approach to encourage greater pro-environmental behavior in tourism? J. Sustain. Tour. 2018, 26, 600-614. [CrossRef]

65. Biswas, A.; Roy, M. Impact of Social Medium on Green Choice Behavior. J. Mark. Manag. 2014, 2, 95-111.

66. Jani, D.; Hwang, Y. User-generated Destination Image through Weblogs: A Comparison of Pre- and Post-visit Images. Asia Pac. J. Tour. Res. 2011, 16, 339-356. [CrossRef]

67. Stylidis, D.; Shani, A.; Belhassen, Y. Testing an integrated destination image model across residents and tourists. Tour. Manag. 2017, 58, 184-195. [CrossRef]

68. Baloglu, S.; McCleary, K.W. A model of destination image formation. Ann. Tour. Res. 1999, 26, 868-897. [CrossRef]

69. Gartner, W.C. Image formation process. J. Travel Tour. Mark. 1994, 2, 191-216. [CrossRef]

70. Kim, H.; Chen, J.S. Destination image formation process: A holistic model. J. Vacat. Mark. 2016, 22, 154-166. [CrossRef]

71. Pike, S. Destination image analysis-A review of 142 papers from 1973 to 2000. Tour. Manag. 2002, 23, 541-549. [CrossRef]

72. Hsu, C.H.C.; Wolfe, K.; Kang, S.K. Image assessment for a destination with limited comparative advantages. Tour. Manag. 2004, 25, 121-126. [CrossRef]

73. Fu, Y.; Timothy, D.J. Social media constraints and destination images: The potential of barrier-free internet access for foreign tourists in an internet-restricted destination. Tour. Manag. Perspect. 2021, 37, 100771. [CrossRef]

74. Woosnam, K.M.; Stylidis, D.; Ivkov, M. Explaining conative destination image through cognitive and affective destination image and emotional solidarity with residents. J. Sustain. Tour. 2020, 28, 917-935. [CrossRef]

75. Chen, C.; Chekalina, T.; Fuchs, M. Social Media and its influence on destination image, tourist satisfaction and behavioral intentions of tourists visiting. In Proceedings of the 7th Advances in Hospitality \& Tourism Marketing \& Management (AHTMM) Conference, Famagusta, Cyprus, 10-15 July 2017; pp. 249-263.

76. Ghazali, R.M.; Cai, L. Social Media Sites in Destination Image Formation. In Tourism Social Media: Transformations in Identity, Community and Culture; Emerald Group Publishing Limited: Binglgy, UK, 2013; Volume 18, pp. 73-86, ISBN 0000018007.

77. Garay, L. \#Visitspain. Breaking down affective and cognitive attributes in the social media construction of the tourist destination image. Tour. Manag. Perspect. 2019, 32, 100560.

78. Marine-Roig, E. Measuring Online Destination Image, Satisfaction, and Loyalty: Evidence from Barcelona Districts. Tour. Hosp. 2021, 2, 62-78. 
79. Wang, H.-Y. Investigating the determinants of travel blogs influencing readers' intention to travel. Serv. Ind. J. 2012, 32, $231-255$. [CrossRef]

80. Zeithaml, V.A.; Berry, L.L. A Conceptual Model of Service Quality and its Implication for Future Research. J. Mark. 1985, 49, 41-50.

81. Berry, L.L.; Parasuraman, A.; Zeithaml, V.A. SERVQUAL: A multiple-item scale for measuring consumer perceptions of service quality. J. Retail. 1988, 64, 12-40.

82. Wang, C.Y.; Hsu, M.K. The relationships of destination image, satisfaction, and behavioral intentions: An integrated model. J. Travel Tour. Mark. 2010, 27, 829-843. [CrossRef]

83. Ramkissoon, H. Authenticity, satisfaction, and place attachment: A conceptual framework for cultural tourism in African island economies. Dev. South. Afr. 2015, 32, 292-302. [CrossRef]

84. WCED. Our Common Future; Oxford University Press: New York, NY, USA, 1987.

85. UNWTO/GTERC Asia Tourism Trends Executive Summary 2019 Edition. Available online: https://www.e-unwto.org/doi/pdf/ 10.18111/9789284421176 (accessed on 10 March 2021).

86. Pan, S.Y.; Gao, M.; Kim, H.; Shah, K.J.; Pei, S.L.; Chiang, P.C. Advances and challenges in sustainable tourism toward a green economy. Sci. Total Environ. 2018, 635, 452-469. [CrossRef]

87. Eftekhari, M.H.; Barzegar, Z.; Isaai, M.T. Web 1.0 to Web 3.0 Evolution: Reviewing the Impacts on Tourism Development and Opportunities. In Human-Computer Interaction, Tourism and Cultural Heritage; Ficarra, F.V.C., de Lozano, C.C., Nicol, E., Andreas, K., Cipolla-Ficarra, M., Eds.; Springer: New York, NY, USA, 2011; pp. 184-195.

88. Kuo, N.-W.; Dai, Y.-Y. Applying the Theory of Planned Behavior to Predict Low-Carbon Tourism Behavior: A Modified Model from Taiwan. Int. J. Technol. Hum. Interact. 2012, 8, 45-62. [CrossRef]

89. Meng, B.; Choi, K. Extending the theory of planned behaviour: Testing the effects of authentic perception and environmental concerns on the slow-tourist decision-making process. Curr. Issues Tour. 2016, 19, 528-544. [CrossRef]

90. Milano, R.; Baggio, R.; Piattelli, R. The effects of online social media on tourism websites. In Proceedings of the International Conference on Information Technology and Travel \& Tourism, Innsbruck, Austria, 26-28 January 2011.

91. Pesonen, J. Tourism Marketing in Facebook: Comparing Rural Tourism SME's and Larger Tourism Companies in Finland. In Information and Communication Technologies in Tourism 2011; Ricci, F.R.M.F., Ed.; Springer: New York, NY, USA, 2011; ISBN 9783709105030.

92. Davis, F.D. User Acceptance of Computer Technology: A Comparison of Two Theoretical Models. Manag. Sci. 1989, 35, 982-1003. [CrossRef]

93. Fishbein, M.; Ajzen, I. Theory-based behavior change interventions: Comments on Hobbis and Sutton. J. Health Psychol. 2005, 10, 27-31. [CrossRef]

94. Chen, S. Using the sustainable modified TAM and TPB to analyze the effects of perceived green value on loyalty to a public bike system. Transp. Res. Part A 2016, 88, 58-72. [CrossRef]

95. Venkatesh, V.; Davis, F.D. A Theoretical Extension of the Technology Acceptance Model: Four Longitudinal Field Studies. Manag. Sci. 2000, 46, 186-204. [CrossRef]

96. Ajzen, I. The Theory of Planned Behavior. Organ. Sci. 1991, 50, 179-211. [CrossRef]

97. Sharmin, F.; Tipu Sultan, M.; Badulescu, D.; Badulescu, A.; Borma, A.; Li, B. Sustainable destination marketing ecosystem through smartphone-based social media: The consumers' acceptance perspective. Sustainability 2021, 13, 2308. [CrossRef]

98. Qu, H.; Kim, L.H.; Im, H.H. A model of destination branding: Integrating the concepts of the branding and destination image. Tour. Manag. 2011, 32, 465-476. [CrossRef]

99. Brislin, R.W. Back-Translation for Cross-Cultural Research. J. Cross. Cult. Psychol. 1970, 1, 185-216. [CrossRef]

100. Lai, W.-H.; Vinh, N.Q. Online Promotion and Its Influence on Destination Awareness and Loyalty in the Tourism Industry. Adv. Manag. Appl. Econ. 2013, 3, 15-30.

101. Joo, Y.; Seok, H.; Nam, Y. The moderating effect of social media use on sustainable rural tourism: A theory of planned behavior model. Sustainability 2020, 12, 4095. [CrossRef]

102. Almeida-Santana, A.; Moreno-Gil, S. Perceived Sustainable Destination Image: Implications for Marketing Strategies in Europe. Sustainability 2019, 11, 6466. [CrossRef]

103. Stylos, N.; Vassiliadis, C.A.; Bellou, V.; Andronikidis, A. Destination images, holistic images and personal normative beliefs: Predictors of intention to revisit a destination. Tour. Manag. 2016, 53, 40-60. [CrossRef]

104. Mohaidin, Z.; Wei, K.T.; Ali Murshid, M. Factors influencing the tourists' intention to select sustainable tourism destination: A case study of Penang, Malaysia. Int. J. Tour. Cities 2017, 3, 442-465. [CrossRef]

105. Yihan Ma Tourism Industry in China- Statistics \& Facts. Available online: https://www.statista.com/topics/1210/tourismindustry-in-china/ (accessed on 2 December 2020).

106. Bush, A.J.; Hair, J.F. An assessment of the mall intercept as a data collection method. J. Mark. Res. 1985, 22, 158-167. [CrossRef]

107. World Statistical Data Shanghai, China Population. Available online: https://www.statista.com/statistics/466938/chinapopulation-of-shanghai/ (accessed on 21 December 2020).

108. Nickerson, R.S. Confirmation bias: A ubiquitous phenomenon in many guises. Rev. Gen. Psychol. 1998, 2, 175-220. [CrossRef]

109. Wang, C.; Zhang, J.; Yu, P.; Hu, H. The theory of planned behavior as a model for understanding tourists' responsible environmental behaviors: The moderating role of environmental interpretations. J. Clean. Prod. 2018, 194, 425-434. [CrossRef] 
110. Park, E.; Choi, B.; Lee, T.J. The role and dimensions of authenticity in heritage tourism. Tour. Manag. 2019, 74, 99-109. [CrossRef]

111. MacCallum, R.C.; Widaman, K.F.; Zhang, S.; Hong, S. Sample size in factor analysis. Psychol. Methods 1999, 4, 84-99. [CrossRef]

112. Kline, R.B. Principles and Practice of Structural Equation Modeling, 4th ed.; The Guildford Press: New York, NY, USA, 2016; ISBN 9781609182304.

113. Hair, J.F.; Black, W.C.; Babin, B.J.; Anderson, R.E. Multiple Data Analysis, 7th ed.; Pearson New International Edition: Essex, UK, 2014; ISBN 978-1-292-02190-4.

114. Sax, L.J.; Gilmartin, S.K.; Bryant, A.N. Assessing Response Rates and Nonresponse Bias in Web and Paper Surveys. Res. High. Educ. 2003, 44, 409-432. [CrossRef]

115. Gerbing, D.W.; Anderson, J.C. Structural equation modeling in practice: A review and recommended two-step approach. Psychol. Bull. 1988, 103, 411-423.

116. Podsakoff, P.M.; MacKenzie, S.B.; Lee, J.Y.; Podsakoff, N.P. Common Method Biases in Behavioral Research: A Critical Review of the Literature and Recommended Remedies. J. Appl. Psychol. 2003, 88, 879-903. [CrossRef]

117. Fuller, C.M.; Simmering, M.J.; Atinc, G.; Atinc, Y.; Babin, B.J. Common methods variance detection in business research. J. Bus. Res. 2016, 69, 3192-3198. [CrossRef]

118. Hundleby, J.D.; Nunnally, J. Psychometric Theory. Am. Educ. Res. J. 1968, 5, 431. [CrossRef]

119. Cronbach, L.J. Coefficient alpha and the internal structure of Tests. Psychometrika 1951, 16, 297-334. [CrossRef]

120. Gefen, D.; Straub, D.; Boudreau, M.-C. Structural Equation Modeling and Regression: Guidelines for Research Practice. Commun. Assoc. Inf. Syst. 2000, 4, 1-77. [CrossRef]

121. Bagozzi, R.P.; Yi, Y. On the evaluation of structural equation models. J. Acad. Mark. Sci. 1988, 16, 74-94. [CrossRef]

122. Fornell, C.; Larcker, D.F. Evaluating Structural Equation Models with Unobservable Variables and Measurement Error. J. Mark. Res. 1981, 18, 39-50. [CrossRef]

123. Bilgihan, A.; Barreda, A.; Okumus, F.; Nusair, K. Consumer perception of knowledge-sharing in travel-related OnlineSocial Networks. Tour. Manag. 2016, 52, 287-296. [CrossRef]

124. Munar, A.M.; Jacobsen, J.K.S. Motivations for sharing tourism experiences through social media. Tour. Manag. 2014, 43, 46-54. [CrossRef]

125. Albert da Silva, M.; Costa, R.A.; Moreira, A.C. The influence of travel agents and tour operators' perspectives on a tourism destination. The case of Portuguese intermediaries on Brazil's image. J. Hosp. Tour. Manag. 2018, 34, 93-104. [CrossRef]

126. Amaro, S.; Duarte, P. Travellers' intention to purchase travel online: Integrating trust and risk to the theory of planned behaviour. Anatolia 2016, 27, 389-400. [CrossRef]

127. Dickinger, A. The trustworthiness of online channels for experience- and goal-directed search tasks. J. Travel Res. 2011, 50, 378-391. [CrossRef]

128. Souiden, N.; Ladhari, R.; Chiadmi, N.E. Destination personality and destination image. J. Hosp. Tour. Manag. 2017, 32, 54-70. [CrossRef]

129. Afrodita, B. Models of Tourist Development in the Context of Regional Development. Ann. Fac. Econ. 2012, XXI, 507-512.

130. Borma, A. Tourism and Local Development. Annals of the "Constantin Brâncuşi”. Univ. Târgu Jiu Econ. Ser. 2015, 2, 76-82.

131. Hyan Yoo, K.; Gretzel, U. The Influence of Perceived Credibility on Preferences for Recommender Systems as Sources of Advice. Inf. Technol. Tour. 2008, 10, 133-146. [CrossRef] 